\title{
Behavior of the vegetable crops section in three types of food retail stores in Campo Grande, Brazil
}

\author{
Dario de O Lima-Filho'; Anderson S Hokama²; Caroline P Spanhol ${ }^{3}$ \\ ${ }^{1}$ UFMS-Depto. Economia e Administração, Av. Senador Filinto Muller, 1.555, 79074-460 Campo Grande-MS; ${ }^{2} \mid$ Graduando em administração; \\ 3Mertrando em agronegócios; dolima@nin.ufms.br; andersonhokama@brturbo.com.br; carolspanhol@gmail.com
}

\begin{abstract}
The behavior of the fresh fruits and vegetable produce section was evaluated, under the point of view of the consumer, in three types of food retail stores in Campo Grande, Brazilian southeast: a grocery store ("quitanda"), a supermarket, and an open-air market. A quantitative-descriptive survey was conducted with 120 individuals, responsible for purchasing fresh fruit and vegetable produce for their homes. To accomplish that, twelve variables were investigated and adapted from the parameters used in the SERVQUAL model, in which the attributes of the retail outlet are pointed out, such as store hygiene and cleanliness and manner by which produce is displayed; employee training traits, such as courtesy and helpfulness; and quality, price range, and variety of the produce for sale. The results reveal that shopping for grocery is done weekly; $80 \%$ of the shoppers interviewed do their shopping in supermarkets and $94 \%$ do theirs in open-air markets. The open-air market had the best results in the attributes for which they were evaluated when compared with the grocery store and the supermarket. The study also points out that the older the shopper the more often he/she does grocery shopping.
\end{abstract}

Keywords: vegetable crops, retail outlet, retail performance, SERVQUAL method.

\section{RESUMO}

Desempenho da seção de hortaliças em equipamentos varejistas de alimentos

Neste estudo foi avaliado, sob o ponto de vista do consumidor, o desempenho da seção de hortaliças em três equipamentos varejistas de alimentos em Campo Grande(MS): uma mercearia (quitanda), um supermercado e uma feira-livre. Foi realizada uma pesquisa quantitativo-descritiva com 120 indivíduos, responsáveis pelas compras de hortaliças para suas residências. Para tanto, foram investigadas doze variáveis adaptadas das dimensões do modelo SERVQUAL, onde se destacam os atributos do equipamento varejista como higiene e limpeza da loja e exposição dos produtos; capacitação dos funcionários como atendimento e cortesia; e atributos do produto como qualidade, variedade e preço. Os resultados mostram que as compras de hortaliças são realizadas semanalmente, sendo que $80 \%$ dos consumidores as realizam em supermercados e $94 \%$ em feiras-livres. A feira livre apresentou o melhor desempenho nos atributos em que foi avaliada quando comparada com a quitanda e o supermercado. Esse estudo, também revela que, quanto maior a idade do consumidor, maior sua freqüência de compra.

Palavras-chave: hortaliças, equipamentos varejistas, desempenho varejista, método SEVQUAL.

(Recebido para publicação em 14 de setembro de 2007; aceito em 22 de outubro de 2008)

(Received in September 14, 2007; accepted in October 22, 2008)

$\mathrm{T}$ he consumption of fresh fruit and vegetable produce (FFV) is present in the diet of the Brazilian population. A survey conducted by Farina (2002) shows that only $44 \%$ of the Brazilian urban population consume fresh fruit and only $58 \%$ use vegetables in their diets. In addition, about $70 \%$ of total FFV demand is concentrated in Brazilian metropolitan regions, such as São Paulo, Rio de Janeiro, and Belo Horizonte.

According to Farina (2002), with regard to FFV sales, a decrease in the participation of open-air markets can be observed, except in the cities of Belo Horizonte, Belém, and São Paulo. Also according to Farina (2002), the open-air market, which was the preferred type of store in São Paulo in the 1980's, has been losing participation quickly. Total sales have decreased by $22 \%$ since 1987 . In view of this, supermarkets have assumed greater importance in FFV sales in other Brazilian regions.

A study conducted by Martins et al. (2007) compared how FFV sales participation in the retail market of the city of São Paulo has evolved at two types of distribution outlets for these products: the open-air market and the supermarket. The authors used the results from the Family Budget Survey (POF - Pesquisa de Orçamento Familiar), versions 1981/82 and 1998/ 99. The results revealed that growth in FFV sales in supermarkets comes from policies that seek to increase the quantities of products offered and to expand the composition of products offered to consumers at the same shopping site, thus preventing the consumer from moving to other sites in search for desired items.
Also according to Martins et al. (2007), FFV quality and variety are important attributes for consumers. Consequently, modern retail companies started to use various logistic tools to monitor and supply the FFV sections of their stores, achieving freshness, quality, and diversity levels similar to those of the array of products found in open-air markets.

Surveys conducted by Bech-Larsen (2000) and Lima-Filho (1999) showed the importance of the FFV section in retail food stores. The Bech-Larsen study revealed that product quality as perceived by the consumer is the most important criterion when selecting a shopping site, followed by store design (layout). Another important factor is brand name, conveyed by the packaging, followed by the perishability and healthy condition of foods. Lima- 
Filho (1999) interviewed 200 women of social classes $\mathrm{A}$ and $\mathrm{B}$ in the city of Campo Grande, and concluded that quality of the FFV section is one of the most important factors for the clients to return to a given supermarket for their shopping.

The objective of this survey was to identify the shopping behavior of vegetable consumers and to determine how do they rate the retail outlet attended. The quality evaluation for the produce section was performed in three sampling units, namely a grocery store (quitanda), a supermarket, and an openair market, in Campo Grande-MS, Brazil. To accomplish that, the variables investigated were based on the SERVQUAL method, which evaluates the quality of services.

\section{MATERIAL AND METHODS}

Initially, an exploratory survey was conducted based on bibliographic and documentary surveys. Next, a quantitative-descriptive study (Malhotra, 1999) was conducted using a structured questionnaire with one hundred and twenty individuals of social classes A/B, responsible for purchasing food for their households. Forty individuals were interviewed at each type of retail outlet surveyed (grocery store, supermarket, and open-air market), during the months of June and July 2005.

Supermarkets typically and predominantly sell fresh and packaged foods as well as hygiene and cleaning items; have a high inventory turnover; work under the self-service concept; and operate with a minimum of two checkout cashiers and a selling area larger than $350 \mathrm{~m}^{2}$ (Saab \& Gimenez, 2000). Grocery stores are identified as small stores with selling areas between 20 and $50 \mathrm{~m}^{2}$, carrying a basic line of foods, such as deli meats and vegetables, in addition to novelty goods, clothes, and office supplies (Parente, 2000). Open-air markets are traditional retail institutions characterized by selling small amounts of vegetables and fruit, with great variety (Colla et al., 2007). They are located near residential areas and also offer readyto-eat foods and craft items.

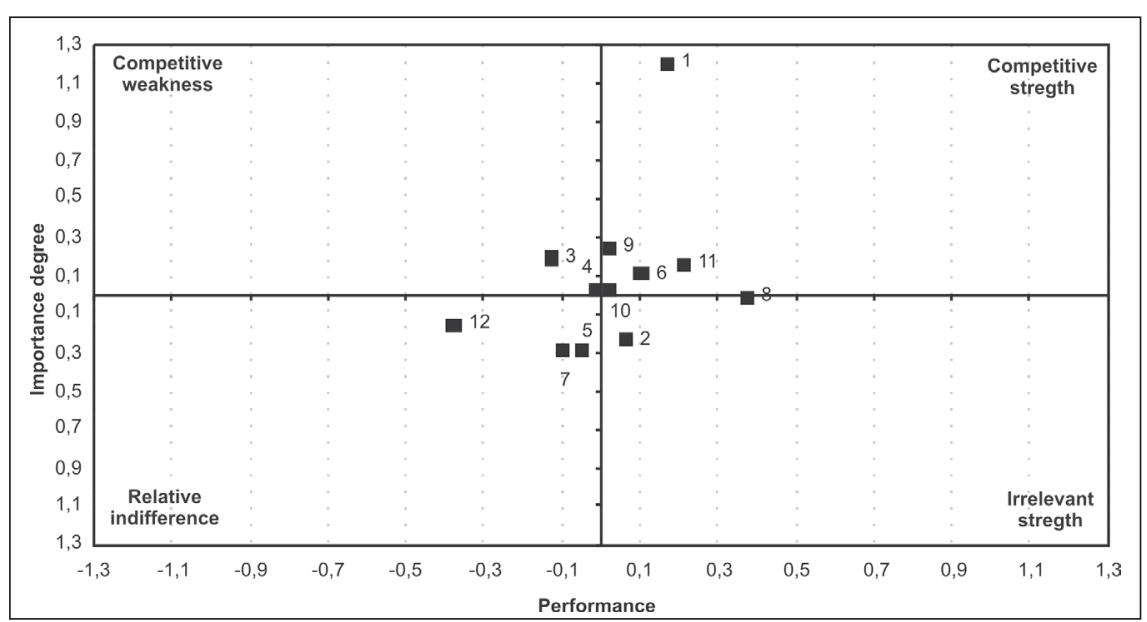

Figure 1. Matrix of grocery store attributes (1) hygiene and cleanliness; (2) product display; (3) product restocking; (4) product replacement; (5) easy access; (6) quality of service by employees; (7) employee knowledge; (8) employee courtesy; (9) quality of packaged products; (10) quality of bulk products; (11) variety, (12) Price (matriz de atributos da mercearia (1) higiene e limpeza; (2) exposição dos produtos; (3) reposição dos produtos; (4) substituição de produtos; (5) facilidade de acesso; (6) atendimento dos funcionários; (7) conhecimento dos funcionários; (8) cortesia dos funcionários; (9) qualidade dos produtos embalados; (10) qualidade dos produtos a granel; (11) variedade, (12) preço). Campo Grande, UFMS, 2005.

The SERVQUAL method (Parasuraman et al., 1985) was used to evaluate service quality in those three types of retail outlets, in order to capture criteria to perceive quality in the services. According to the authors, clients evaluate service quality by comparing what they want (expectations) against what they get (performance). To accomplish that, the SERVQUAL method suggests the analysis of the following measures: (i) empathy (verified through the helpful service of employees); (ii) reliability: (measured by proper service specifications); (iii) responsibility (observed from immediate service to the client); (iv) safety (verified by the level of courtesy in providing information and the technical knowledge of company members); (v) tangible aspects (the environment and the individual as a representation of the company's attitude).

Based on the SERVQUAL method, the following variables were obtained:

Retail Outlet Attributes: (1) store hygiene and cleanliness; (2) product display; (3) product restocking in shelves; (4) replacement of damaged/ spoiled products; (5) easy access to products. Employee training: (6) service provided by employees; (7) employee knowledge about the products; (8) employee courtesy and friendliness. Product attributes: (9) quality of packaged products; (10) quality of bulk products; (11) variety of products in the vegetables section; (12) relative prices charged by the retail outlet.

Data analysis was divided into two steps: the first refers to the performance analysis of the three retail outlets surveyed; in this step we employed the calculation of the difference between performance and expectation means; in the second step, we applied the chisquare test to detect potential associations between variables.

\section{RESULTS AND DISCUSSION}

The vegetable consumer profile analysis for Campo Grande allowed the identification of some of their habits, such as shopping frequency. There exist a great number of consumers that choose to do their shopping for vegetables weekly: $80 \%$ in the supermarket and $94 \%$ in the open-air market. This fact can be explained by the perishability of those products, which characterizes them as products with high shopping recurrence. It can also be said that shopping frequency is strongly associated with shopping days, that is, vegetable 


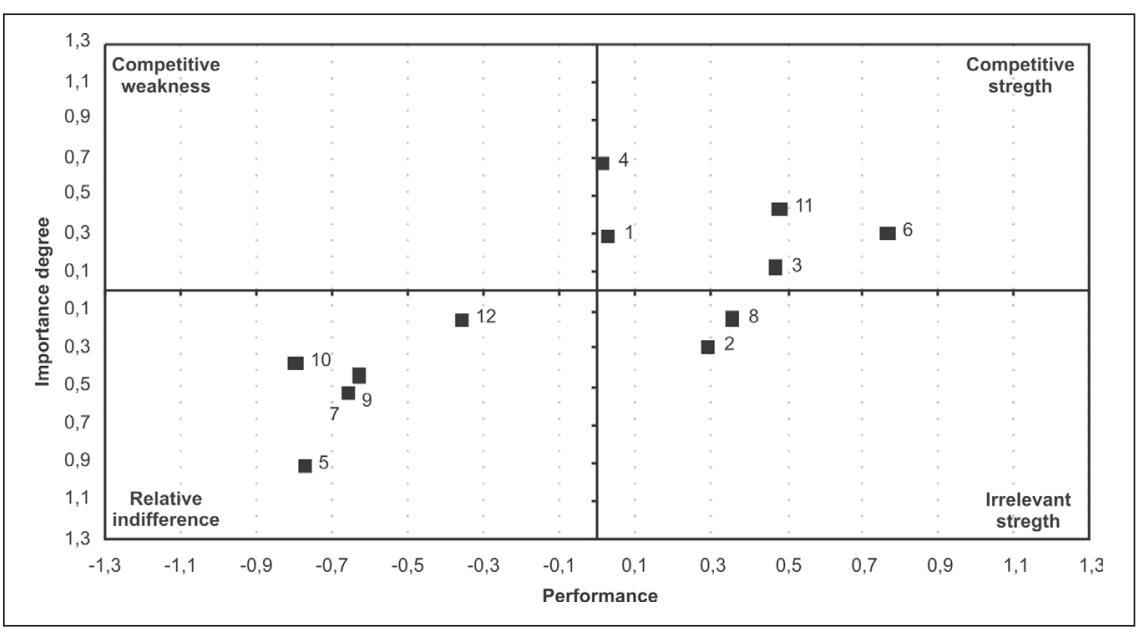

Figure 2. Matrix of open-air market attributes (1) hygiene and cleanliness; (2) product display; (3) product restocking; (4) product replacement; (5) easy access; (6) quality of service by employees; (7) employee knowledge; (8) employee courtesy; (9) quality of packaged products; (10) quality of bulk products; (11) variety, (12) price (matriz de Atributos da Feira-Livre (1) higiene e limpeza; (2) exposição dos produtos; (3) reposição dos produtos; (4) substituição de produtos; (5) facilidade de Acesso; (6) atendimento dos funcionários; (7) conhecimento dos funcionários; (8) cortesia dos funcionários; (9) qualidade dos produtos embalados; (10) qualidade dos produtos a granel; (11) variedade, (12) preço). Campo Grande, UFMS, 2005.

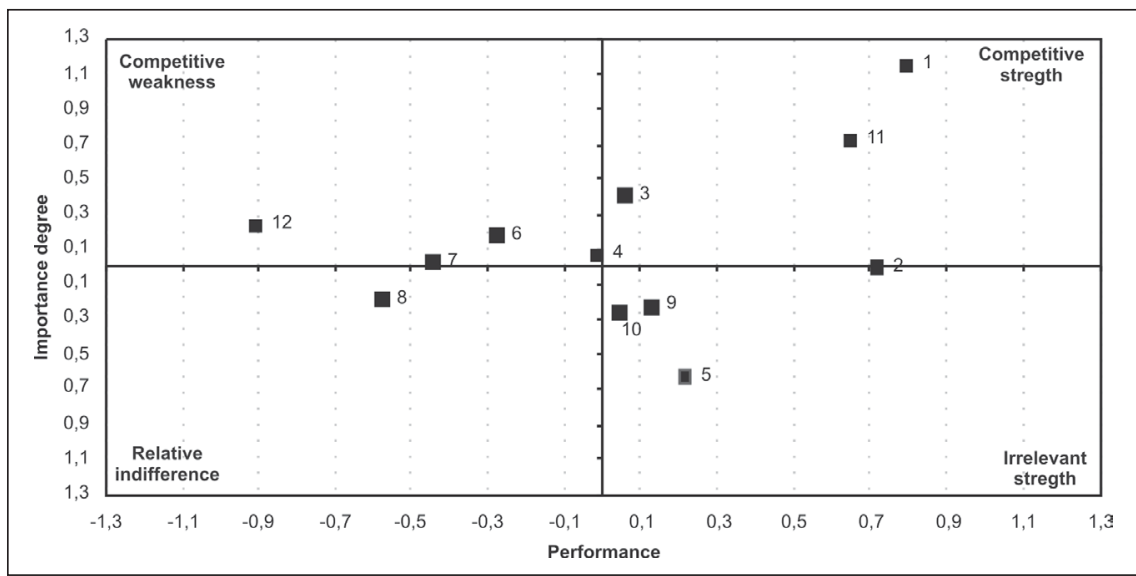

Figure 3. Matrix of supermarket attributes (1) hygiene and cleanliness; (2) product display; (3) product restocking; (4) product replacement; (5) easy access; (6) quality of service by employees; (7) employee knowledge; (8) employee courtesy; (9) quality of packaged products; (10) quality of bulk products; (11) variety, (12) price (matriz de atributos do supermercado(1) higiene e limpeza; (2) exposição dos produtos; (3) reposição dos produtos; (4) substituição de produtos; (5) facilidade de acesso; (6) atendimento dos funcionários; (7) conhecimento dos funcionários; (8) cortesia dos funcionários; (9) qualidade dos produtos embalados; (10) qualidade dos produtos a granel; (11) variedade, (12) preço). Campo Grande, UFMS, 2005

purchases are concentrated on promotion days, such as "green" Wednesdays and Thursdays in supermarkets and Saturdays in open-air markets.

In order to become acquainted with consumers in Campo Grande, we measured the performance of the sampling units with respect to consumer
Figure 1, are in the central area of the graph, known as the gray zone (Albrecht $\&$ Bradford, 2000). This position occurs when the importance of the attribute being evaluated is neither high nor low in the consumer's opinion, but has satisfactory performance. In this case, because it does not have a superior performance, the grocery store cannot be discriminated from the competitors in relation to the attributes for which it was evaluated. Among the attributes that fall in this area, the following are highlighted: employee knowledge, product restocking and replacement, easy access, product display, and employee service. The matrix of attributes for the grocery store (quitanda) also shows an isolated point. It refers to the store hygiene and cleanliness attribute. Therefore, this attribute is located in an area known as normal or competitive power. This position signals that the attributes evaluated are highly important, with great performance in the consumer's opinion.

The second type of retail trade surveyed was the open-air market. This type of retail outlet offers fruit and vegetables and provides food services, as well as imported and craft products. It can be seen from Figure 2 that the points are dispersed. There is a small concentration of attributes in the areas of relative indifference and competitive power, and only two attributes in the area of irrelevant superiority. The first area is in a position where both performance and attribute importance are relatively low, therefore consisting of a position of relative indifference with regard to the service provided, in the consumer's opinion. Among those attributes, the following are important: employee knowledge about the foods, easy access to products, and relative product price. The second area illustrates that attributes have great importance for the consumer and have high performance; these attributes are considered the outlet's competitive power.

If, on the one hand, attributes such as variety, employee service, product restocking, and product variety make up the company's competitive power, attributes such as product display and 
employee courtesy, on the other, have little importance for the consumer, in spite of their high performance.

The third retail outlet surveyed was the supermarket. The matrix of attributes shows some dispersion of attributes within it; however, there is little concentration of attributes in the areas of competitive vulnerability and competitive power. Only two attributes are in the area of irrelevant superiority (Figure 3). The attributes located in the competitive vulnerability (or image loss) area are attributes with high importance for the consumer, but with low performance. Among the attributes located in this area are: product price, employee knowledge and service, and bulk product quality.

The supermarket shows some attributes of great importance for the consumer and high performance, such as: store hygiene and cleanliness, product restocking, and variety. As mentioned above, the supermarket has high performance in two other attributes: easy access, and packaged product quality; however, the consumer gives little importance to those, placing them in the area known as irrelevant superiority area.

By using the SERVQUAL method, we were able to identify the consumer's expectation in Campo Grande and the performance of retail outlets with respect to the service level offered. The perception of quality by consumers with regard to the retail outlets surveyed is represented in Figure 4. It should be pointed out that the performance shown by the retail outlet should correspond to consumers' expectations; in other words, and for analysis purposes, the difference between expectation and performance means should be equal to zero. As a consequence, the open-air market and the grocery store (quitanda) had performances equal to the consumer's expectations in the employee knowledge and bulk product quality attributes (Figure 4). This implies that the consumers' expectations are being met by the retail outlets they attend, without, however, being different from their competitors, since they do not deliver a superior value to the consumer in the form of added services.

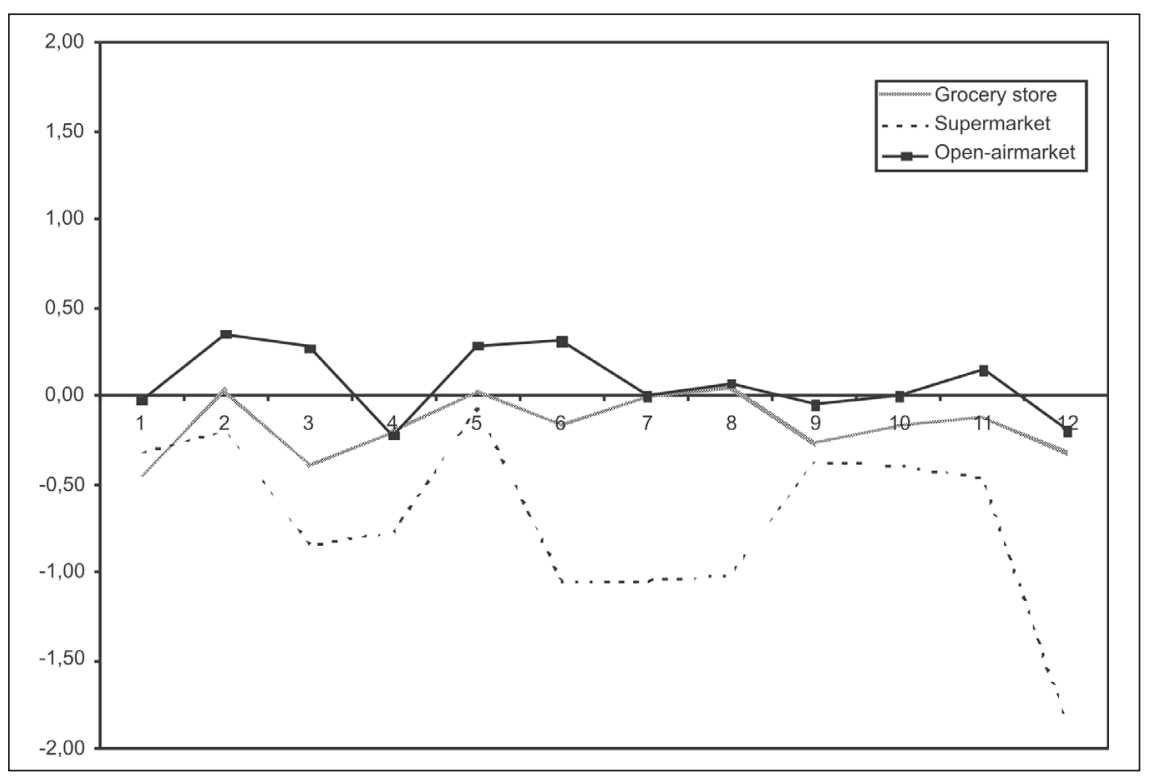

Figure 4. Difference between performance means and expectations in the supermarket, grocery store, and open-air market formats. (1) hygiene and cleanliness; (2) product display; (3) product restocking; (4) product replacement; (5) easy access; (6) quality of service by employees; (7) employee knowledge; (8) employee courtesy; (9) quality of packaged products; (10) quality of bulk products; (11) variety, (12) price (diferença entre as médias de desempenho e expectativa nos formatos de supermercado, mercearia e feira livre (1) higiene e limpeza; (2) exposição dos produtos; (3) reposição dos produtos; (4) substituição de produtos; (5) facilidade de acesso; (6) atendimento dos funcionários; (7) conhecimento dos funcionários; (8) cortesia dos funcionários; (9) qualidade dos produtos embalados; (10) qualidade dos produtos a granel; (11) variedade, (12) preço). Campo Grande, UFMS, 2005.

The open-air market performance is above consumer's expectations for the attributes: product display and restocking, easy access to products, employee service, and product variety. The grocery store performance was higher than the consumer's expectations for the employee courtesy attribute. Performance in the other attributes, with the exception of employee knowledge and bulk product quality, already discussed, was a little lower; stores should pay attention to those aspects to meet the consumer's expectations and deliver higher value in that regard to achieve consumer satisfaction. The supermarket performance was lower than consumer's expectations in all attributes for which it was evaluated. The relative food price attribute had the poorest performance in the consumer's opinion. The attributes related to employee training, such as service and courtesy also had a low performance level.

By comparing the demographic profile of the interviewees with their evaluation of quality, the existence of an association between the variables age and nutritional value $(\mathrm{p}<0.05)$ can be observed in two retail outlets: the supermarket and the open-air market. Consequently, it is suggested that the greater the age of the individual the greater his/her concern about the nutritional value of foods. However, such association was not verified in the grocery store type of outlet (quitanda). Possibly the purchase of products from that type of store occurs in the form of home restocking, that is, small quantities are purchased each time. Consequently, a concern about health and the nutritional value of foods rests with the main types of retail stores, i.e., supermarkets and open-air markets.

An association $(\mathrm{p}<0.05)$ can also be seen between the variables education and propensity of consumers to pay premium prices for fresh vegetables. In other words, the higher the level of education, the greater the consumer's willingness to pay a little extra for fresh vegetables in the grocery store and 
supermarket outlets. Such association was not observed for open-air market consumers.

An association $(\mathrm{p}<0.05)$ was also observed between age and shopping frequency in two types of retail outlets: the supermarket and the open-air market. This occurrence can be explained by the fact that older consumers in social classes $\mathrm{A} / \mathrm{B}$, consisting mostly of retired people, have more free time available for shopping. This association was not verified for the grocery store. This result can be explained by the fact that older individuals in social classes $\mathrm{A} / \mathrm{B}$ live together with other people that carry out minor shopping activities.

These results were also observed in the study by Lima-Filho (1999), which aimed to investigate the association between the variables age and shopping frequency. Therefore, the statement can be made that there is a tendency according to which the greater the age of consumers the greater their shopping frequency.

The present work assumes that the importance of the quality of services provided to consumers is necessary for retail organizations to achieve aboveaverage performances. Guivant et al. (2003) stated that, in addition to their concern about meeting ever higher consumer requirements, supermarkets should act as agents in the process of transformation of the food consumption sphere. Their capacity to develop new food consumption options is becoming stronger, with more and more important initiatives with regard to innovations and food quality choices.

The SERVQUAL method proved adequate for the proposed type of analysis. Biscola \& Lima-Filho (2006) arrived at the same conclusion while studying the quality of self-services provided by retail banks. In future studies, it is suggested that new surveys, both quantitative and qualitative, be conducted for a better understanding about consumer motivations when buying VEGETABLES. Such studies are required because they allow organizations, especially agroindustries, to better adapt their supply to demand, as well as to envisage new market opportunities.

\section{ACKNOWLEDGMENTS}

We thank CNPq for financial support during this study.

\section{REFERENCES}

ALBRECHT K; BRADFORD LJ. 2000. Serviços com qualidade: a vantagem competitiva. São Paulo: Makron Books do Brasil.

BECH-LARSEN T. 2000. The haven of the self-service store: a study of the fruit and vegetable department's influence on customer attitudes towards food chain stores. Available in: <http:// $130.226 .203 .239 / \mathrm{pub} / \mathrm{mapp} / \mathrm{wp} /$ wp70.pdf >. Accessed in: June 20, 2005.

BELIK W; CHAIM NA. 1999. Formas híbridas de coordenação na distribuição de frutas, legumes e verduras no Brasil. Revista de Cadernos de Debate. VII Núcleo de estudos e pesquisas em alimentação. UNICAMP, 1999.

BÍSCOLA PHN; LIMA-FILHO DO. 2006. Qualidade percebida dos serviços de autoatendimento: um estudo no varejo bancário brasileiro. Revista de Ciências da Administração 8; 47-62.

COLLA C; STADUTO JAR; ROCHA JUNIOR WF; RINALDI RN. 2007. A escolha da feira-livre como canal de distribuição para produtos da agricultura familiar de Cascavel/ PR. In: Congresso da Sober, XLV, 2007. Anais... [CD-ROM]. Londrina-PR, Sober.
FARINA EMMQ. 2002. Consolidation, multinationalization and competition in Brazil: impacts on horticulture and dairy products systems. Development Policy Review 20: 441-458.

GUIVANT J; FONSECA MF; RAMOS FSV; SCHEIWEZER M. 2003. Os supermercados e o consumo de frutas, legumes e verduras (FLV) orgânicos certificados. Available in: <http://www.planetaorganico.com.br/ trabflv.htm>. Accesses in: August 12, 2005.

LIMA-FILHO DO. 1999. Valor percebido e o comportamento do consumidor de supermercado: um estudo exploratório em uma média cidade brasileira. São Paulo: Fundação Getúlio Vargas. (Tese doutorado).

MACHADO EL. 2002. O papel da reputação na coordenação vertical da cadeia produtiva das frutas, legumes e verduras frescos. São Paulo. Available in: <http:// www.teses.usp.br/teses/disponiveis/12/ 12138/tde-22082003-200807/>. Accessed in: April 2, 2005.

MAINVILLE DY; PETERSON CH. 2005. Fresh Produce Procurement Strategies in a Constrained Supply Environment: Case Study of Companhia Brasileira de Distribuição. Review of Agricultural Economics 27: 130-138.

MALHOTRA NK. 1999. Marketing research: an applied orientation. $3^{\text {rd }}$ ed. New York: Prentice-Hall.

MARTINS VA; MARGARIDO MA; BUENO CRF. 2007. Alteração no perfil de compra de frutas, legumes e verduras nos supermercados e feiras livres na cidade de São Paulo. Informações Econômicas 37: 30-37. Available in: ftp://ftp.sp.gov.br/ ftpiea/publicacoes/tec3-0207.pdf. Accessed in October 10, 2007.

PARASURAMAN A; ZEITHAM VA; BERRY LL. 1985. A conceptual model of service quality and its implications for future research. Journal of Marketing 49: 41-50.

PARENTE J. 2000. Varejo no Brasil: gestão e estratégia. São Paulo: Atlas.

SAAB WGL; GIMENEZ LCP. Aspectos atuais do varejo de alimentos no mundo e no Brasil. Available in: http://www.bndes.gov.br/ conhecimento/bnset/set1106.pdf. Accessed in October 10, 2007.

SOLOMON MR. 2002. O comportamento do consumidor: comprando, possuindo $e$ sendo. 5. ed. Porto Alegre: Bookman. 